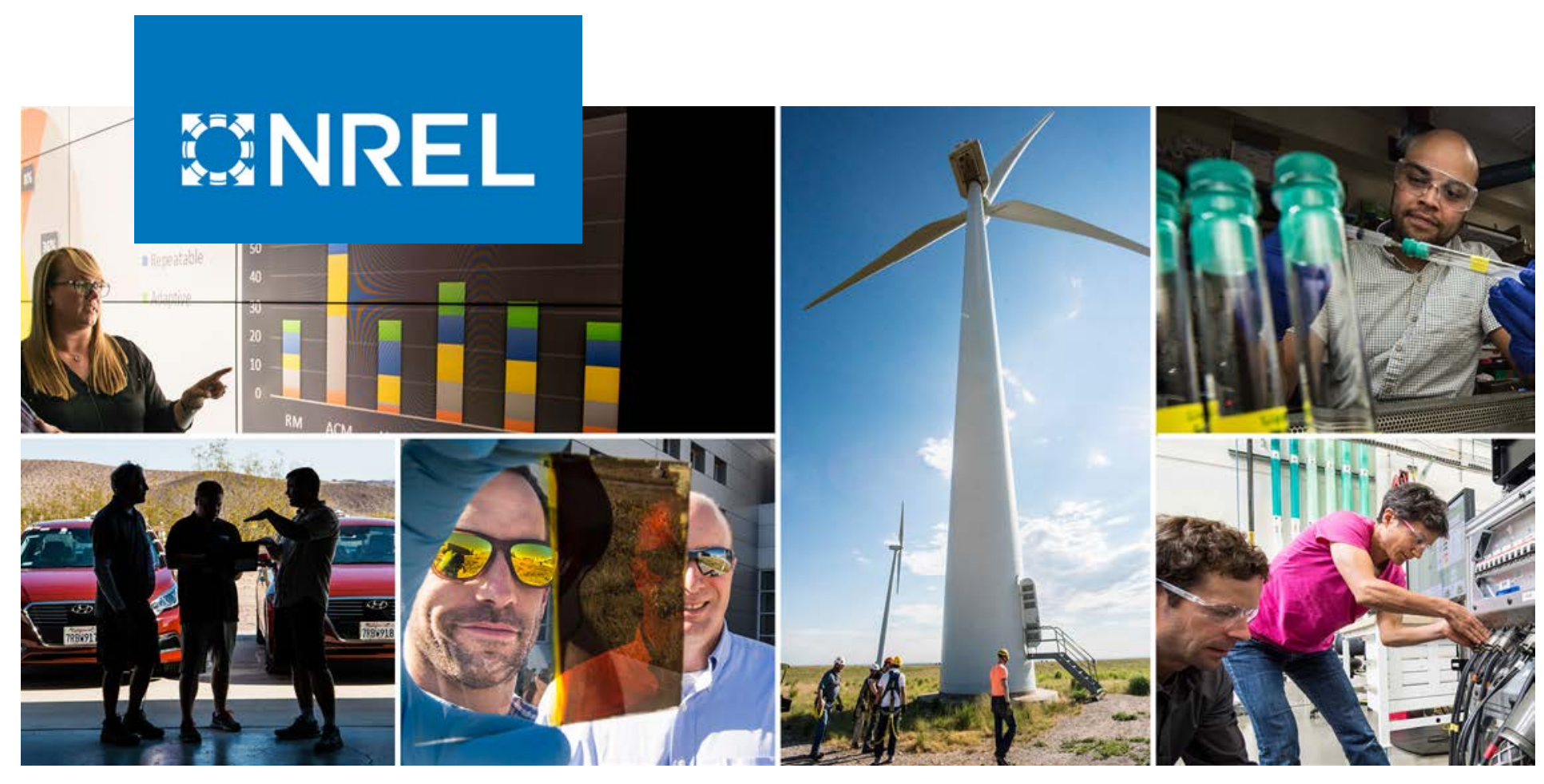

\title{
Jamaica Urban Transit Company Drive-Cycle Analysis
}

Mark Singer and Caley Johnson

National Renewable Energy Laboratory

NREL is a national laboratory of the U.S. Department of Energy

Office of Energy Efficiency \& Renewable Energy

Operated by the Alliance for Sustainable Energy, LLC

This report is available at no cost from the National Renewable Energy Laboratory (NREL) at www.nrel.gov/publications.

\section{Technical Report}

NREL/TP-5400-73381

April 2019 


\section{GHREL}

\section{Jamaica Urban Transit Company Drive-Cycle Analysis}

Mark Singer and Caley Johnson

National Renewable Energy Laboratory

\section{Suggested Citation}

Singer, Mark, and Caley Johnson. 2019. Jamaica Urban Transit Company Drive-Cycle Analysis. Golden, CO: National Renewable Energy Laboratory. NREL/TP-5400-73381. https://www.nrel.gov/docs/fy19osti/73381.pdf.

NREL is a national laboratory of the U.S. Department of Energy Office of Energy Efficiency \& Renewable Energy Operated by the Alliance for Sustainable Energy, LLC

This report is available at no cost from the National Renewable Energy Laboratory (NREL) at www.nrel.gov/publications.

Contract No. DE-AC36-08GO28308
Technical Report NREL/TP-5400-73381 April 2019

National Renewable Energy Laboratory 15013 Denver West Parkway Golden, CO 80401 303-275-3000 • www.nrel.gov 


\section{NOTICE}

This work was authored by the National Renewable Energy Laboratory, operated by Alliance for Sustainable Energy, LLC, for the U.S. Department of Energy (DOE) under Contract No. DE-AC36-08G028308. Funding provided by the Department of State, U.S Department of State Office of Global Change in the Bureau of Oceans, and International Environmental and Scientific Affairs and U.S Department of Energy Office of International Affairs. The views expressed herein do not necessarily represent the views of the DOE or the U.S. Government.

This report is available at no cost from the National Renewable Energy Laboratory (NREL) at www.nrel.gov/publications.

U.S. Department of Energy (DOE) reports produced after 1991 and a growing number of pre-1991 documents are available free via www.OSTI.gov.

Cover Photos by Dennis Schroeder: (clockwise, left to right) NREL 51934, NREL 45897, NREL 42160, NREL 45891, NREL 48097, NREL 46526.

NREL prints on paper that contains recycled content. 


\section{Acknowledgments}

The authors would like to thank Gerald Lindo of the U. S. Agency for International Development for his guidance throughout this project. They would also like to thank the following people for sharing their insight and offering guidance and valuable data: Selena Mohammed-Wilson and Carla Barrett (Jamaican Urban Transit Company); Michael Saunderson (National Works Agency); and Adam Duran, Eric Miller, and Lauren Lynch (National Renewable Energy Laboratory). This report has benefitted greatly from these people's help, but any mistakes are entirely the authors' responsibility. 


\section{List of Acronyms}

BEB battery electric bus

DRIVE Drive-Cycle Rapid Investigation, Visualization, and Evaluation (analysis tool)

FASTSim Future Automotive Systems Technology Simulator

JUTC Jamaica Urban Transit Company

$\mathrm{km} \quad$ kilometer

kph kilometers per hour

kWh kilowatt-hour

NREL National Renewable Energy Laboratory 


\section{Table of Contents}

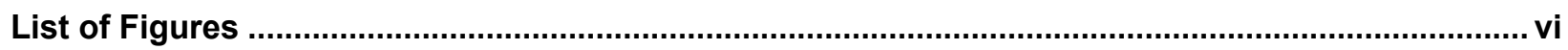



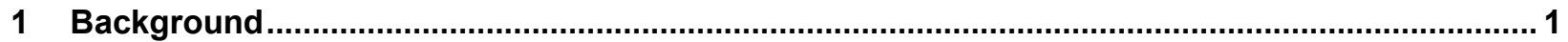

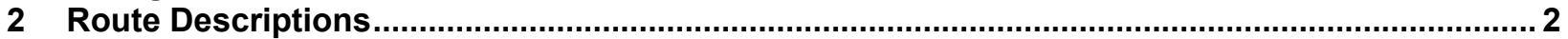



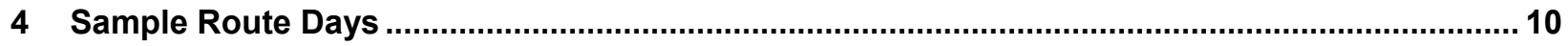

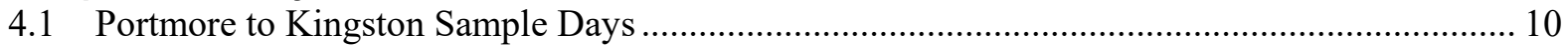

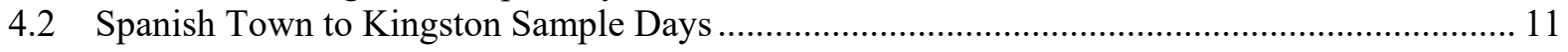



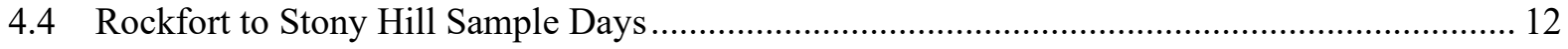

5 Estimated Battery Electric Bus Fuel Economy .................................................................. 14

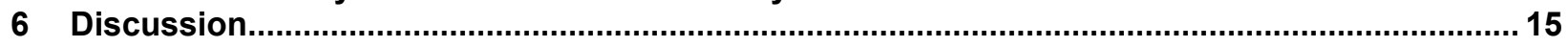






\section{List of Figures}

Figure 1. Naggo Head Drive R.A.B. to Half Way Tree Transport Centre geography ............................... 3

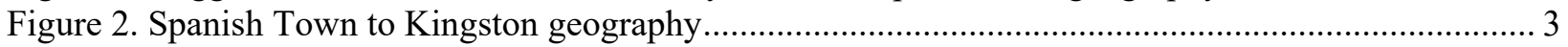

Figure 3. Half Way Tree Transport Centre to Stony Hill geography ......................................................... 4

Figure 4. JUTC bus stops per kilometer and average driving speed .................................................... 6

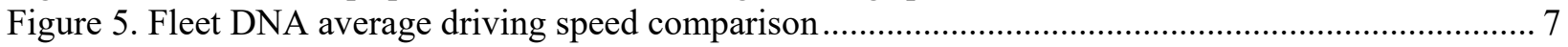

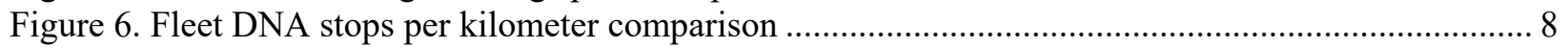

Figure 7. Fleet DNA average driving speed and number of stops ................................................ 8

Figure 8. Fleet DNA kinetic intensity and average driving speed ..................................................... 9

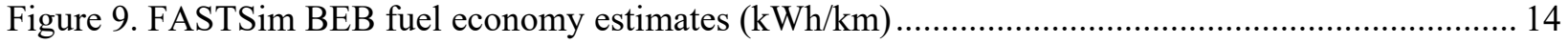

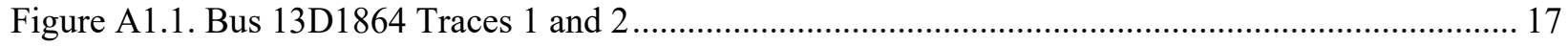

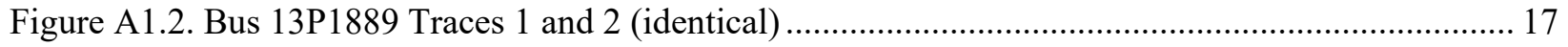

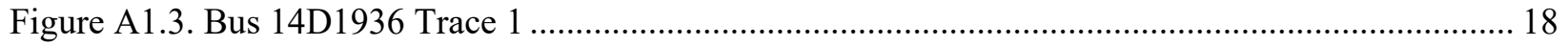

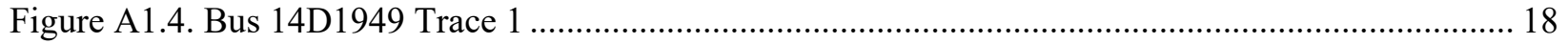

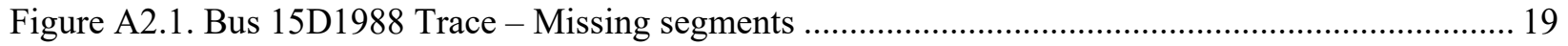

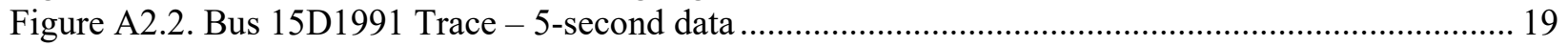

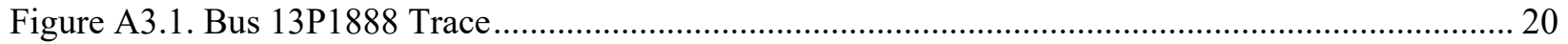

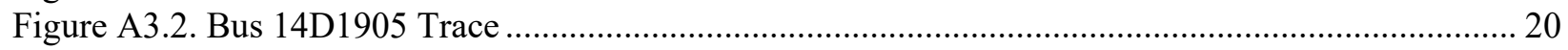

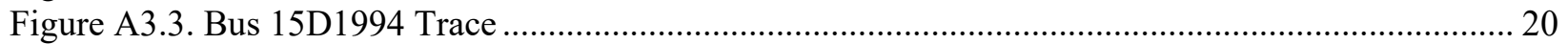

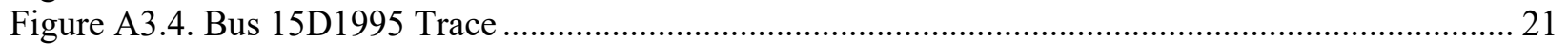



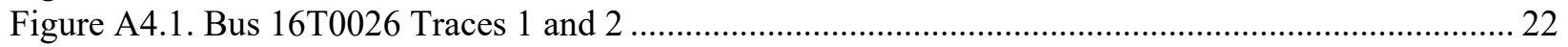

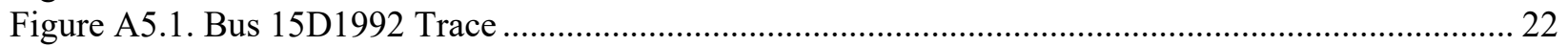

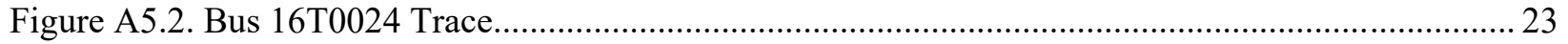

\section{List of Tables}

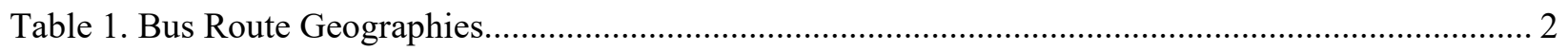

Table 2. Bus Drive-Cycle Statistics ................................................................................. 5

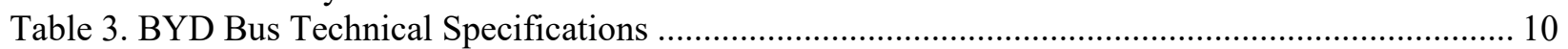

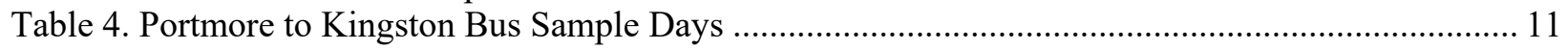

Table 5. Spanish Town to Kingston Bus Sample Days ......................................................................... 11

Table 6. Spanish Town to Denbigh Sample Day (December 11, 2017) ............................................. 12

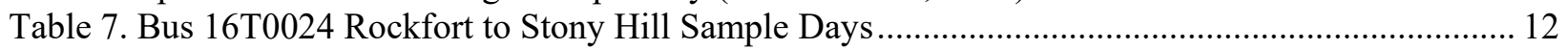




\section{Background}

The National Renewable Energy Laboratory (NREL) partnered with the Jamaica Urban Transit Company (JUTC) to investigate the suitability of implementing battery electric buses (BEBs) on JUTC bus routes in the Kingston vicinity. Suitability depends partially on vehicle drive-cycle data including vehicle speed at any given second over a time period of use. In December 2017, NREL captured drive-cycle data for select buses to define the utilization patterns of existing buses and to estimate which routes could be best suited for electrification based on (1) the ability of available BEB options to cover the route distance while allowing sufficient time to recharge, and (2) the route drive-cycle statistics that would allow for the greatest energy efficiency gains from switching from a diesel bus to a BEB. Typically drive-cycles reflecting more stop-and-start driving provide better opportunities for electric-drive vehicles that regenerate electricity during braking. 


\section{Route Descriptions}

NREL worked with JUTC to install data loggers on JUTC buses to track their operation from December 9 through December 15, 2017. The data loggers captured 1-Hz data second-bysecond, tracking the vehicles' speed and global positioning system location as latitude and longitude. Prior to deployment of the data loggers, NREL worked with JUTC to determine which buses covered routes known to have congestion issues and may be of most interest for possible electrification or other efficiency efforts. Table 1 lists the buses that were tracked. Appendix A includes maps of all route trace data.

Table 1. Bus Route Geographies

\begin{tabular}{lllll}
\hline Vehicle ID & $\begin{array}{l}\text { Vehicle } \\
\text { Year }\end{array}$ & Vehicle Make & $\begin{array}{l}\text { Vehicle } \\
\text { Model }\end{array}$ & Route Geography \\
\hline 13D1864 & 2013 & Volvo & VDL & Portmore to Kingston \\
13P1889 & 2013 & Volvo & VDL & Portmore to Kingston \\
14D1936 & 2014 & Volvo & VDL & Portmore to Kingston \\
14D1949 & 2014 & Volvo & VDL & Portmore to Kingston \\
15D1988 & 2015 & Volvo & VDL & Portmore to Kingston - Missing segments \\
15D1991 & 2015 & Volvo & VDL & Portmore to Kingston - 5-second data \\
13P1888 & 2013 & Volvo & VDL & Spanish Town to Kingston \\
13P1898 & 2013 & Volvo & VDL & Spanish Town to Kingston \\
14D1905 & 2014 & Volvo & VDL & Spanish Town to Kingston \\
15D1994 & 2015 & Volvo & VDL & Spanish Town to Kingston \\
15D1995 & 2015 & Volvo & VDL & Spanish Town to Kingston \\
15D1998 & 2015 & Volvo & VDL & Spanish Town to Kingston \\
15D1992 & 2015 & Volvo & VDL & Spanish Town to Kingston and Montego Bay \\
16T0026 & 2016 & Golden Dragon & & Spanish Town to Denbigh \\
16T0024 & 2016 & Golden Dragon & & Rockfort to Kingston to Stony Hill \\
\hline
\end{tabular}

Most of the tracked buses covered routes between Portmore and Kingstown and routes from Spanish Town to Kingston. However, several buses covered more diverse geographies beyond these areas. One of the Spanish Town to Kingston buses, 15D1992, included significant travel north to Montego Bay. A single bus, 16T0026, operated on a route from Spanish Town west to Denbigh, and a single bus, 16T0024, operated out of Rockfort and covered a geography from Kingston north to Stony Hill and beyond to Above Rocks and the Border Terminus bus station.

The National Works Agency provided NREL with three primary road segments of interest for analysis efforts based on areas of known congestion issues that might benefit from efficient vehicle technologies. These included a segment from Naggo Head Drive R.A.B. to the Half Way Tree Transport Centre with a focus on Hagley Road from Three Miles to the Half Way Tree Transport Centre. The logged bus routes from Portmore to Kingston primarily covered these segments (Figure 1). 


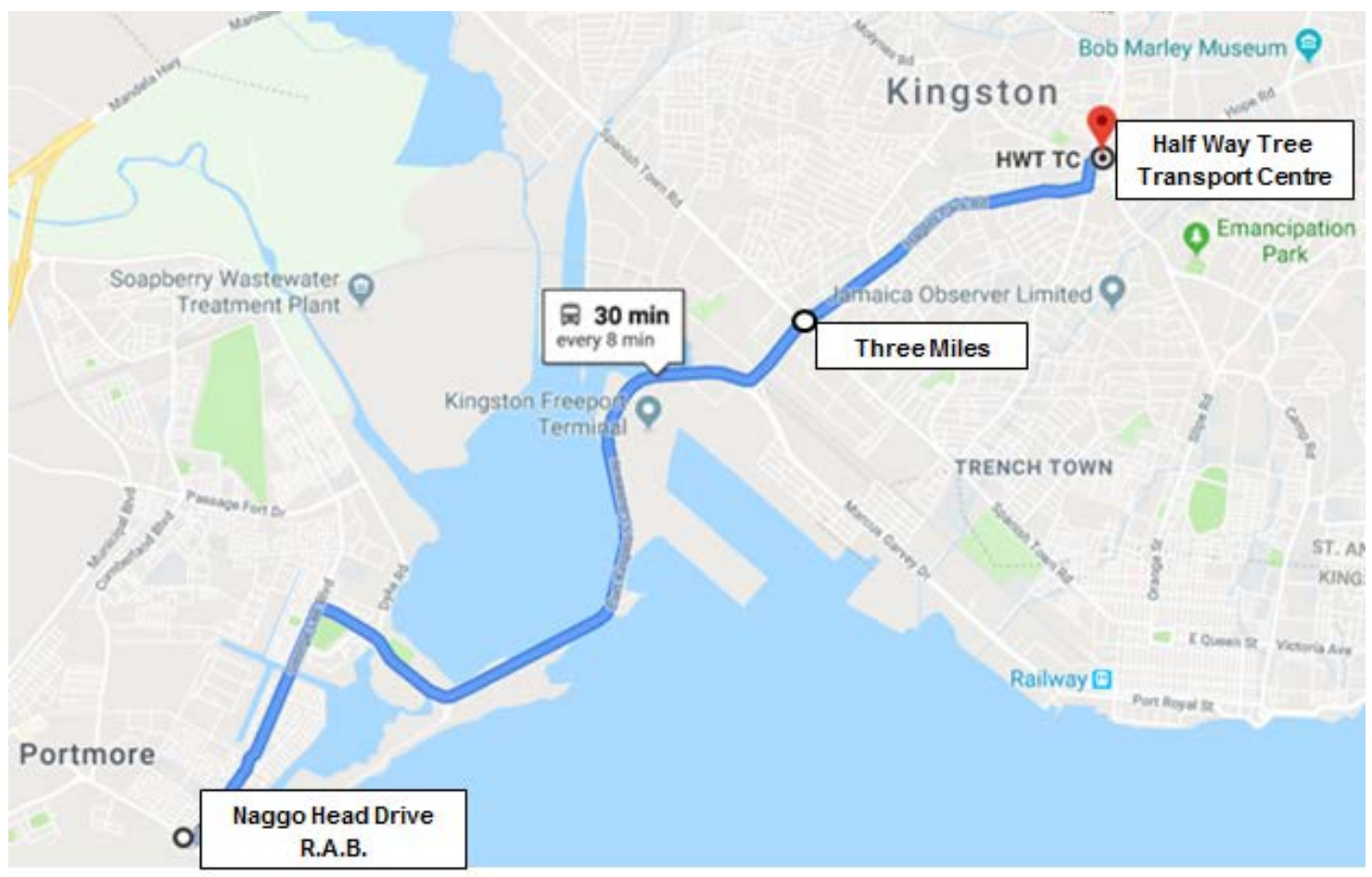

Figure 1. Naggo Head Drive R.A.B. to Half Way Tree Transport Centre geography (Google 2019)

The second segment of interest was from Spanish Town to the Down Town area of Kingston, with a focus on the Mandela Highway from the Inland Revenue bus station to the Opposite New Haven bus station. The logged bus routes from Spanish Town to Kingston primarily covered these geographies (Figure 2).

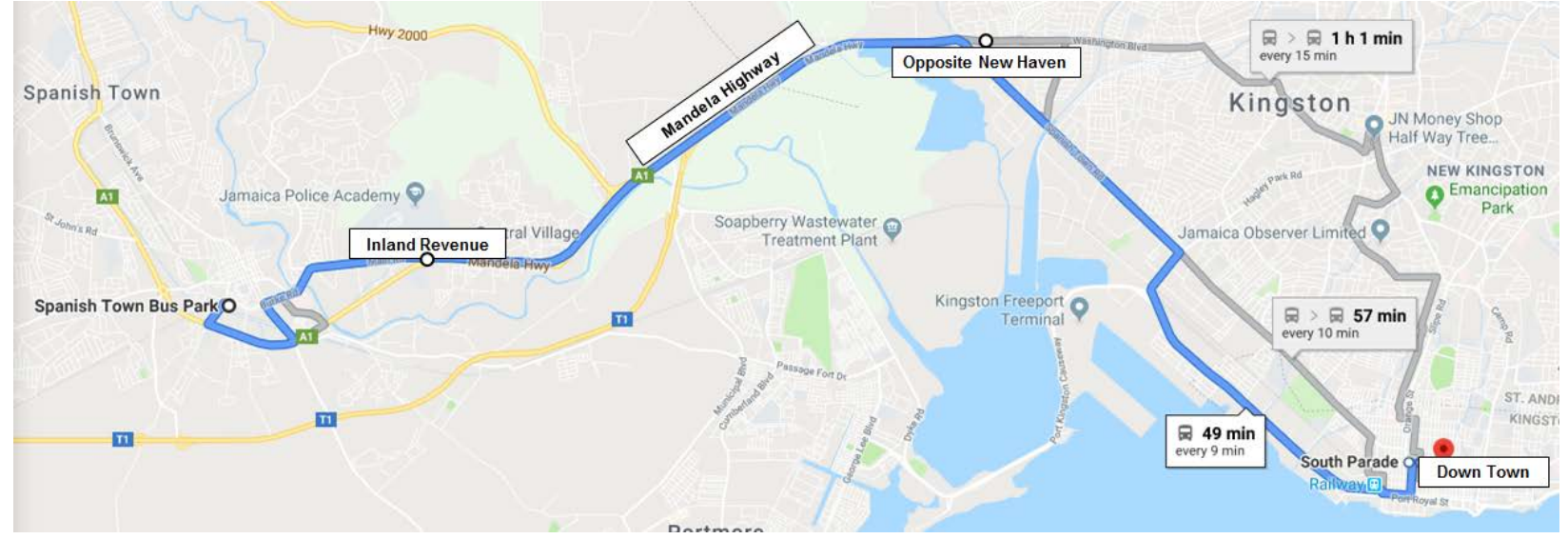

Figure 2. Spanish Town to Kingston geography (Google 2019)

The third segment of interest is from the Half Way Tree Transport Centre north to Stony Hill. This segment was covered by bus 16T0024, which operated out of the Rockfort bus depot and covered Kingston and the area north to Stony Hill and beyond (Figure 3). 


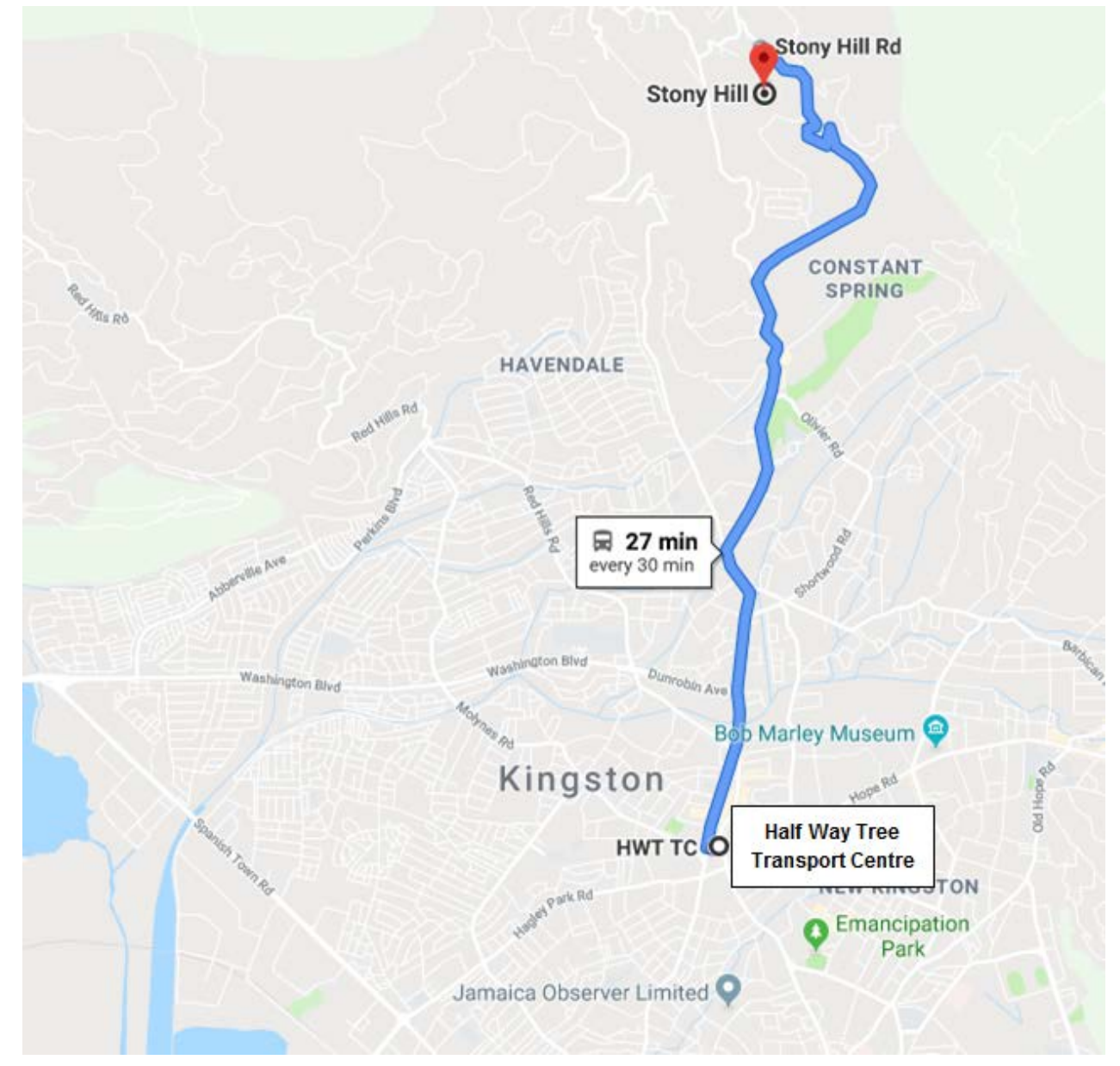

Figure 3. Half Way Tree Transport Centre to Stony Hill geography (Google 2019) 


\section{Route Statistics}

NREL used the Drive-Cycle Rapid Investigation, Visualization, and Evaluation (DRIVE) analysis tool (NREL 2013) to analyze the JUTC bus drive cycles. DRIVE accepts the global positioning system data captured by the data loggers and cleans the data by removing erroneous data (e.g., sudden extremely high or low velocities) and repairing short periods in the log where data are missing. DRIVE then provides summary statistics of the resulting drive cycles. Table 2 displays the primary drive-cycle statistics studied, which are related to distance traveled, speed, and number of stops. Table 2 introduces kinetic intensity values, which will be discussed in more detail later in this section.

Table 2. Bus Drive-Cycle Statistics

\begin{tabular}{|c|c|c|c|c|c|c|c|}
\hline Group & Vehicle ID & $\begin{array}{l}\text { Distance } \\
\text { Traveled } \\
(\mathbf{k m})\end{array}$ & $\begin{array}{l}\text { Average } \\
\text { Speed } \\
\text { (kph) }\end{array}$ & $\begin{array}{l}\text { Maximum } \\
\text { Speed } \\
\text { (kph) }\end{array}$ & $\begin{array}{l}\text { Total } \\
\text { Stops }\end{array}$ & $\begin{array}{l}\text { Stops per } \\
\text { Kilometer }\end{array}$ & $\begin{array}{l}\text { Kinetic } \\
\text { Intensity } \\
(1 / \mathbf{k m})\end{array}$ \\
\hline \multirow{7}{*}{$\begin{array}{l}\text { Portmore to } \\
\text { Kingston }\end{array}$} & 13D1864 - Trace 1 & 380 & 30 & 92 & 740 & 2.0 & 1.0 \\
\hline & 13D1864 - Trace 2 & 507 & 31 & 73 & 901 & 1.8 & 0.9 \\
\hline & 13P1889 - Trace 1 & 210 & 28 & 74 & 452 & 2.2 & 1.0 \\
\hline & 13P1889 - Trace 2 & 536 & 30 & 74 & 997 & 1.9 & 1.0 \\
\hline & 14D1936 & 497 & 31 & 85 & 979 & 2.0 & 1.0 \\
\hline & 14D1949 & 171 & 35 & 71 & 254 & 1.5 & 0.9 \\
\hline & $\begin{array}{l}\text { Portmore to } \\
\text { Kingston Overall }\end{array}$ & 2,301 & 30 & 92 & 4,334 & 1.9 & 1.0 \\
\hline \multirow{6}{*}{$\begin{array}{l}\text { Spanish } \\
\text { Town to } \\
\text { Kingston }\end{array}$} & 13P1888 & 197 & 24 & 73 & 551 & 2.8 & 1.2 \\
\hline & 14D1905 & 586 & 27 & 93 & 1,297 & 2.2 & 1.1 \\
\hline & 15D1994 & 167 & 30 & 73 & 331 & 2.0 & 0.7 \\
\hline & 15D1995 & 316 & 27 & 71 & 705 & 2.2 & 1.0 \\
\hline & 15D1998 & 569 & 31 & 68 & 892 & 1.6 & 1.1 \\
\hline & $\begin{array}{l}\text { Spanish Town to } \\
\text { Kingston Overall }\end{array}$ & 1,835 & 28 & 93 & 3,782 & 2.1 & 1.0 \\
\hline \multirow{3}{*}{$\begin{array}{l}\text { Spanish } \\
\text { Town to } \\
\text { Denbigh }\end{array}$} & 16T0026 - Trace 1 & 804 & 32 & 71 & 914 & 1.1 & 0.8 \\
\hline & 16T0026 - Trace 2 & 531 & 32 & 71 & 594 & 1.1 & 0.9 \\
\hline & $\begin{array}{l}\text { Spanish Town to } \\
\text { Denbigh Overall }\end{array}$ & 1,334 & 32 & 71 & 1,508 & 1.1 & 0.9 \\
\hline Montego Bay & 15D1992 & 918 & 33 & 89 & 1,360 & 1.5 & 0.6 \\
\hline Stony Hill & $16 \mathrm{~T} 0024$ & 497 & 24 & 68 & 1,024 & 2.1 & 2.1 \\
\hline
\end{tabular}

Two of the buses that logged travel from Portmore to Kingston were excluded: the logger for bus 15D1991 captured data every 5 seconds, and bus 15D1988 travelled large distances where the signal was lost by the logger, resulting in large gaps in the captured cycle. 
Data loggers were deployed primarily covering two time periods. The initial deployment covered December 9 through December 12, 2017. The second deployment covered December 13 through December 17, 2017. Daily averages cannot be inferred from the totals in Table 2 as the buses were not equally active across all days and the logs did not all start and stop at the same time for each bus. Section 4 covers individual day statistics. Three buses (13D1864, 16T0026, and 16T0026) were covered during both deployments. These separate deployments are referred to as Trace 1 and Trace 2 in Table 2. The data for the individual bus traces for Portmore to Kingston, Spanish Town to Kingston, and Spanish Town to Denbigh were analyzed individually and as a combined drive cycle for each group.

Overall, 6,886 kilometers $(\mathrm{km})$ were covered by the logs summarized in Table 2. The Portmore to Kingston and the Spanish Town to Kingston routes covered $60 \%$ of the total distance. The average speed was calculated based on non-idle driving speeds while the buses were in motion. The routes did not vary greatly by average speed, and most logs averaged between 27 and 33 kilometers per hour (kph). The Stony Hill route had the lowest average speed ( $24 \mathrm{kph})$, and one of the Portmore to Kingston traces had the highest average speed ( $35 \mathrm{kph})$. The average speed of the overall Portmore to Kingston drive cycle was higher than the average speed of the overall Spanish Town to Kingston cycle. The Denbigh route had a higher average speed than either of the primary groups. Average speed can be greatly affected by the number of stops a bus makes.

DRIVE calculates the average number of stops per kilometer for the buses. A stop in this instance is any time where a bus comes to a stop and does not represent just the official passenger stops. The majority of the JUTC buses averaged between 1.1 and 2.2 stops per kilometer. One of the Spanish Town to Kingston buses averaged a higher 2.8 stops per kilometer.

Figure 4 shows the relationship of the JUTC bus average driving speed and their number of stops per kilometer. In general, those buses that stop more often have a lower average driving speed. These represent drive cycles that include more stop-and-start driving than those cycles where average driving speed is higher due to fewer stops.



Figure 4. JUTC bus stops per kilometer and average driving speed

NREL maintains Fleet DNA (NREL 2018), a database of commercial fleet data from across a broad number of applications on routes in the United States. NREL used the Fleet DNA database to measure how the JUTC buses compare to example cycles of other mass transit buses. At the 
time of this study, there were 472 days of driving from 19 mass transit buses included in the available Fleet DNA data.

Figure 5 shows that JUTC buses overall have a similar average driving speed in comparison to the buses in the Fleet DNA database where buses averaged $34 \mathrm{kph}$. The slowest of the JUTC bus routes studied, Stony Hill, is found to also have a relatively slow speed compared to the transit buses captured in the Fleet DNA database.

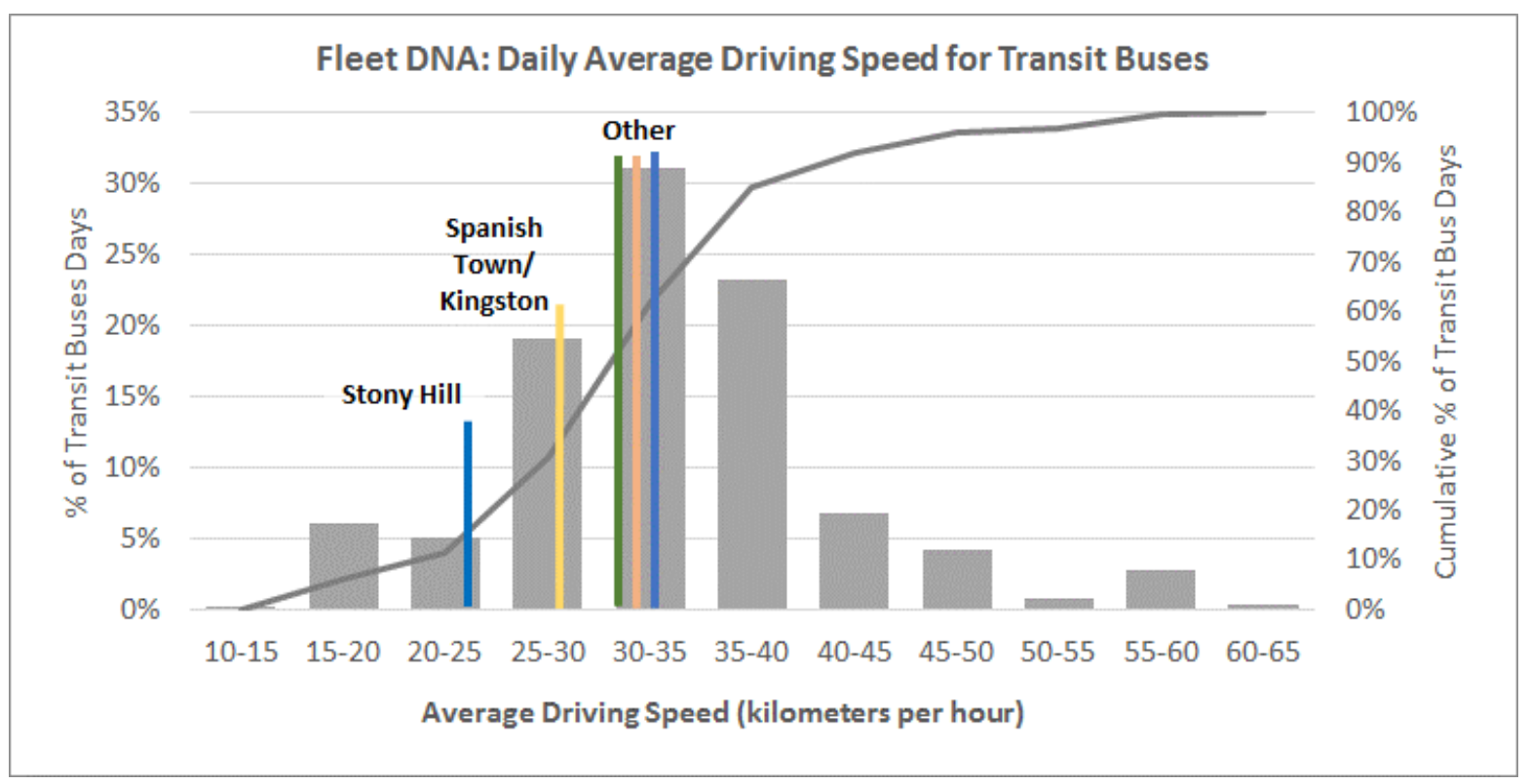

Figure 5. Fleet DNA average driving speed comparison

Figure 6 shows that JUTC buses generally stop more frequently than the average Fleet DNA mass transit bus, which averages 1.3 stops per kilometer. The Spanish Town to Kingston and Stony Hill routes are shown to have stops per kilometer higher than $87 \%$ of buses in the Fleet DNA database. 


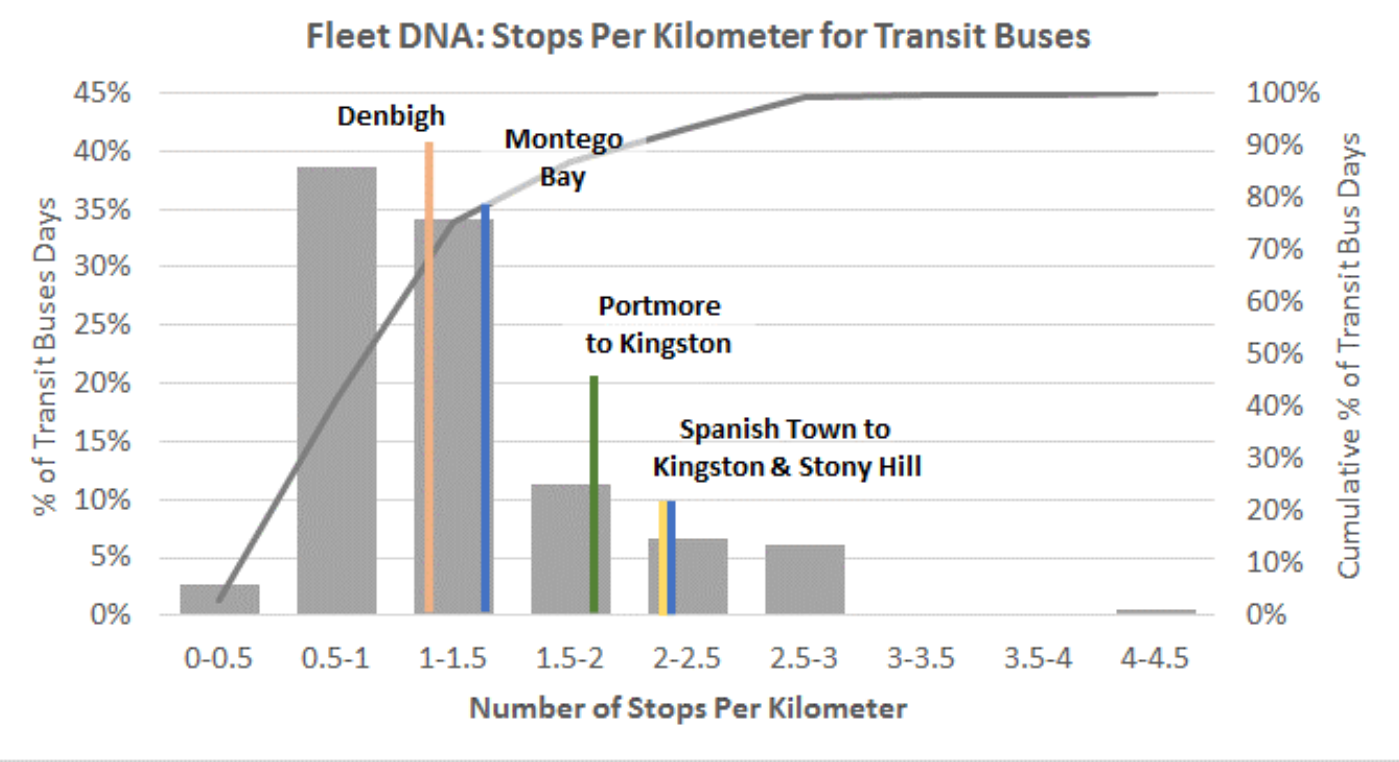

Figure 6. Fleet DNA stops per kilometer comparison

Figure 7 shows that when JUTC buses are compared to buses more broadly on the combination of these metrics, JUTC buses have similar average driving speeds for their number of stops. This would indicate the JUTC buses are accelerating and/or decelerating similarly to the buses in the Fleet DNA database.

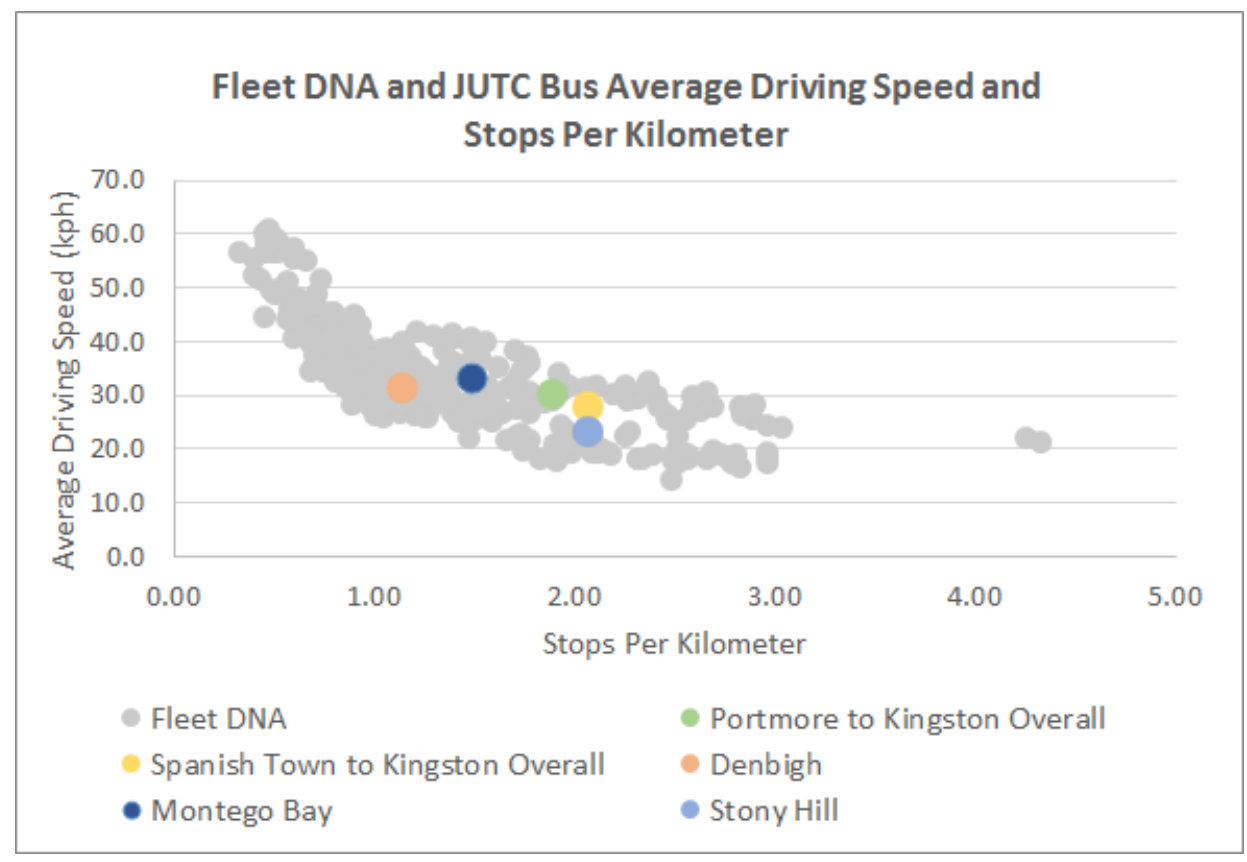

Figure 7. Fleet DNA average driving speed and number of stops

Kinetic intensity, as shown in Table 2, measures the amount of stop-and-start driving in the drive cycle. The metric is calculated by dividing the characteristic acceleration of the drive cycle by the aerodynamic speed. The characteristic acceleration describes the energy used to accelerate 
the vehicle, and the aerodynamic speed describes the energy consumed by drag forces $(\mathrm{O}$ 'Keefe et al. 2007). The higher stop-and-start driving in drive cycles with higher kinetic intensities can be beneficial for electric-drive vehicles that regenerate electricity during braking. In this way, identifying drive cycles with higher kinetic intensities can help determine which cycles would be good candidates for electrification.

Figure 8 compares the kinetic intensities of the JUTC bus drive cycles with the Fleet DNA database. Most JUTC bus kinetic intensities ranged from 0.6 to 1.2 (in units of $1 /$ kilometer), which is lower than or equal to the average Fleet DNA bus kinetic intensity of 1.2. However, the Stony Hill route had a comparatively high kinetic intensity at 2.1 (in units of $1 /$ kilometer). This would suggest the Stony Hill route might be a good route to focus on for further BEB deployment evaluation. It should be noted that at the time of this study elevation changes were not incorporated in the drive-cycle analyses. Much of the JUTC bus routes do not cover terrain with large elevation changes. However, the Stony Hill route and the Montego Bay route include significant elevation changes that could affect the results in a more detailed analysis.



Figure 8. Fleet DNA kinetic intensity and average driving speed 


\section{Sample Route Days}

BEBs are constrained by the driving range of the battery and the time required to recharge the battery. A BEB deployment may be most successful when the bus operates a fixed route where the bus will not need to travel beyond the range of the battery pack and the route schedule will allow the bus to return to a charging location for a sufficient period to recharge the battery.

For the purposes of this study, NREL considered the bus options available from BYD and the bus technical specifications detailed on the BYD website (BYD Motors 2018). BYD buses were chosen for this study due to the company's existing presence in Latin America (BYD Motors 2018). Other leading BEB manufacturers such as Proterra were more focused in the United States at the time of the study (Proterra 2019). The specifications as used in this report are meant as a starting point for evaluation. Onsite testing of specific vehicles of interest should be considered at an appropriate time to validate ranges under local driving conditions. Table 3 shows the ranges of available BYD buses at the time of the study were from 232 to 322 kilometers.

Table 3. BYD Bus Technical Specifications

\begin{tabular}{lllll}
\hline BYD Bus & $\begin{array}{l}\text { Length } \\
(\text { meters })\end{array}$ & $\begin{array}{l}\text { Curb Weight } \\
(\mathrm{kg})\end{array}$ & $\begin{array}{l}\text { Range } \\
(\mathrm{km})\end{array}$ & $\begin{array}{l}\text { Charging } \\
\text { Time }(\mathrm{hr})\end{array}$ \\
\hline K11 & 18.5 & 21,600 & 322 & 3 \\
K9 & 12.5 & 14,000 & 259 & $3-4$ \\
K9s & 10.9 & 13,000 & 233 & $3-4$ \\
K7 & 9.4 & 9,698 & 232 & $2-3$ \\
\hline
\end{tabular}

Note: Data from BYD Motors, http://en.byd.com/bus/ accessed 7/13/2018

NREL investigated sample routes across the different bus geographies to determine if the reported BYD bus ranges would be sufficient for specific daily driving distances. BYD reported the required time for a full charge to be between 2 and 4 hours depending on the specific bus. NREL assumed most charging would occur overnight or while buses were out of service.

\subsection{Portmore to Kingston Sample Days}

A majority of the Portmore to Kingston routes were covered by buses 13D1864 and 13P1889. The route traces for these vehicles are included in Appendix A. The traces for 13P1889 show a more compact route compared to those of 13D1864 during the period tracked. Both buses covered the Naggo Head Drive R.A.B. to the Half Way Tree Transport Centre segment of interest, while bus 13D1864 also covered the Hagley Road segment of interest.

Table 4 shows sample days for the buses of interest. Bus 13P1889 appeared to have two primary active trips with a period of over 2 hours where the bus sat in the Portmore depot. The bus started the morning shortly before 6:00 AM, was back in the Portmore depot between 11:30 AM and 1:30 PM, at which time it returned to service until shortly after 8:00 PM. The bus was then out of service until the next morning. In total, the bus traveled 208 kilometers for the day. During the active periods of trip 1 and trip 2, the data loggers recorded nearly 5 hours where the bus was not moving and was sitting idle. This is separate from the time between the trips and is understood to 
be the times where the bus was in use but stopped in traffic, at passenger pick-up locations, or potentially in the depot.

Table 4. Portmore to Kingston Bus Sample Days

\begin{tabular}{|c|c|c|c|c|c|c|c|}
\hline $\begin{array}{l}\text { Bus Number } \\
\text { Date: Trip }\end{array}$ & $\begin{array}{l}\text { Start } \\
\text { Location }\end{array}$ & $\begin{array}{l}\text { End } \\
\text { Location }\end{array}$ & $\begin{array}{l}\text { Start } \\
\text { Time }\end{array}$ & $\begin{array}{l}\text { End } \\
\text { Time }\end{array}$ & $\begin{array}{l}\text { Total } \\
\text { Time } \\
\text { (hr:min) }\end{array}$ & $\begin{array}{l}\text { Distance } \\
\text { Traveled } \\
(\mathrm{km})\end{array}$ & $\begin{array}{l}\text { Idle } \\
\text { Time } \\
\text { (hr:min) }\end{array}$ \\
\hline $\begin{array}{l}\text { 13P1889 } \\
\text { Dec. } 13,2017: \text { Trip } 1\end{array}$ & Portmore & Portmore & 5:50 AM & 11:24 AM & $5: 33$ & 103 & $2: 15$ \\
\hline $\begin{array}{l}\text { 13P1889 } \\
\text { Dec. 13, 2017: Trip } 2\end{array}$ & Portmore & Portmore & 1:38 PM & 8:07 PM & $6: 28$ & 105 & $2: 35$ \\
\hline $\begin{array}{l}\text { 13D1864 } \\
\text { Dec. 11, 2017: Trip } 1\end{array}$ & Portmore & Portmore & 5:35 AM & 10:36 PM & $17: 00$ & 311 & $7: 00$ \\
\hline
\end{tabular}

Bus 13D1864 operated in a similar route geography as bus 13P1889, but there was more variability in the time of use across the days of operation. Table 4 details an example day where the bus began operation at about 5:30 AM in Portmore, operated for 17 hours, and finished the day back in Portmore. The bus covered 311 kilometers and was idle for 7 hours over the day.

If charging were available at the Portmore depot, assuming a BEB started the day at full charge with the range of 259 kilometers such as the BYD K9, the hypothetical BEB would be able to cover the full day of travel by 13P1889. In this example, the bus would not need to charge during the day but would have an opportunity for a partial charge between trips. The bus would then need to charge after both trips overnight to reach full charge for the next day.

The same hypothetical BEB would not be able to cover the 311 kilometers of bus 13D1864. However, the 7 hours of idle time recorded by the logger may point to an opportunity to charge during the time of service if a significant portion of that time were in the depot.

\subsection{Spanish Town to Kingston Sample Days}

Buses 13P1888 and 15D1995 covered the Mandela Highway segment of interest while covering the Spanish Town to Kingston primary route of interest. Table 5 shows sample days for these buses.

Table 5. Spanish Town to Kingston Bus Sample Days

\begin{tabular}{llllllll}
\hline $\begin{array}{l}\text { Bus Number } \\
\text { Date: Trip }\end{array}$ & $\begin{array}{l}\text { Start } \\
\text { Location }\end{array}$ & $\begin{array}{l}\text { End } \\
\text { Location }\end{array}$ & $\begin{array}{l}\text { Start } \\
\text { Time }\end{array}$ & $\begin{array}{l}\text { End } \\
\text { Time }\end{array}$ & $\begin{array}{l}\text { Total } \\
\text { Time } \\
\text { (hr:min) }\end{array}$ & $\begin{array}{l}\text { Distance } \\
\text { Traveled } \\
\text { (km) }\end{array}$ & $\begin{array}{l}\text { Idle } \\
\text { Time } \\
\text { (hr:min) }\end{array}$ \\
\hline $\begin{array}{l}\text { 13P1888 } \\
\text { Dec. 11, 2017: Trip 1 }\end{array}$ & $\begin{array}{l}\text { Spanish } \\
\text { Town }\end{array}$ & $\begin{array}{l}\text { Spanish } \\
\text { Town }\end{array}$ & 5:57 AM & 10:02 PM & 16:05 & 196 & $7: 54$ \\
\hline $\begin{array}{l}\text { 15D1995 } \\
\text { Dec 12, 2017: Trip 1 }\end{array}$ & $\begin{array}{l}\text { Spanish } \\
\text { Town }\end{array}$ & $\begin{array}{l}\text { Spanish } \\
\text { Town }\end{array}$ & 5:56 AM & 9:54 PM & $15: 58$ & 205 & $6: 22$ \\
\hline
\end{tabular}

The days for these buses were very similar. The buses were active throughout the day from shortly before 6:00 AM and until completing their service near 10:00 PM. Each bus covered about 200 kilometers for their respective days. 
If charging were available at the Spanish Town depot, the hypothetical BEB with a range of 259 kilometers would be able to complete the days of service for each of these buses. The buses would need to charge overnight to start the next day with a full charge. The buses sat idle between 6 to 8 hours in each of these days. If a significant portion of that time were spent in the same depot, there may be an opportunity for a partial recharge during the day.

\subsection{Spanish Town to Denbigh Sample Day}

Although not traveling a primary route of interest, a sample day of bus 16T0026 was investigated. The bus started the morning at 5:02 AM at the Spanish Town depot, traveled 131 kilometers, was out of service in Denbigh from 9:38 AM until 2:28 PM, or nearly 5 hours, and returned to service, completing 134 kilometers of travel and ending the day at the Spanish Town Depot at 8:55 PM. One sample day is presented in Table 6.

Table 6. Spanish Town to Denbigh Sample Day (December 11, 2017)

\begin{tabular}{llllllll}
\hline $\begin{array}{l}\text { Bus } \\
\text { Number } \\
\text { Trip }\end{array}$ & $\begin{array}{l}\text { Start } \\
\text { Location }\end{array}$ & $\begin{array}{l}\text { End } \\
\text { Location }\end{array}$ & $\begin{array}{l}\text { Start } \\
\text { Time }\end{array}$ & End Time & $\begin{array}{l}\text { Total } \\
\text { Time } \\
\text { (hr:min) }\end{array}$ & $\begin{array}{l}\text { Distance } \\
\text { Travelled } \\
\text { (km) }\end{array}$ & $\begin{array}{l}\text { Idle } \\
\text { Time } \\
\text { (hr:min) }\end{array}$ \\
\hline $\begin{array}{l}\text { 16T0026 } \\
\text { Trip 1 }\end{array}$ & Spanish Town & Denbigh & 5:02 AM & $9: 38$ AM & $4: 36$ & 131 & $0: 52$ \\
\hline $\begin{array}{l}\text { 16T0026 } \\
\text { Trip 2 }\end{array}$ & Denbigh & $\begin{array}{l}\text { Spanish } \\
\text { Town }\end{array}$ & 2:28 PM & 8:55 PM & $6: 27$ & 134 & $1: 41$ \\
\hline
\end{tabular}

If a charging station were available at the Spanish Town depot, the hypothetical BEB with a range of 259 kilometers would not be able to complete the sample day total of 265 kilometers for the Denbigh route without charging during the day. The extended stay in Denbigh may allow for additional charging time if a charging station were available at the Denbigh location. The bus sat idle for a relatively short period of time while in service, providing little potential for additional charging during the times of service. The bus would need to charge overnight to start the next day with a full charge.

\subsection{Rockfort to Stony Hill Sample Days}

Bus 16T0024 from the Rockfort depot completed routes covering the Stony Hill route of interest. Two sample days are presented in Table 7.

Table 7. Bus 16T0024 Rockfort to Stony Hill Sample Days

\begin{tabular}{llllllll}
\hline $\begin{array}{l}\text { Date } \\
\text { Trip Number }\end{array}$ & $\begin{array}{l}\text { Start } \\
\text { Location }\end{array}$ & $\begin{array}{l}\text { End } \\
\text { Location }\end{array}$ & $\begin{array}{l}\text { Start } \\
\text { Time }\end{array}$ & End Time & $\begin{array}{l}\text { Total } \\
\text { Time } \\
\text { (hr:min) }\end{array}$ & $\begin{array}{l}\text { Distance } \\
\text { Traveled } \\
\text { (km) }\end{array}$ & $\begin{array}{l}\text { Idle } \\
\text { Time } \\
\text { (hr:min) }\end{array}$ \\
\hline $\begin{array}{l}\text { Dec. 13, 2017 } \\
\text { Trip 1 }\end{array}$ & Rockfort & Rockfort & 4:30 AM & 4:13 PM & $11: 42$ & 213 & $3: 39$ \\
\hline $\begin{array}{l}\text { Dec. 14, 2017 } \\
\text { Trip 1 }\end{array}$ & Rockfort & $\begin{array}{l}\text { Half Way } \\
\text { Tree }\end{array}$ & 5:10 AM & 11:01 AM & $5: 51$ & 105 & $1: 16$ \\
\hline $\begin{array}{l}\text { Dec. 14, 2017 } \\
\text { Trip 2 }\end{array}$ & $\begin{array}{l}\text { Half Way } \\
\text { Tree }\end{array}$ & Rockfort & 2:08 PM & 8:30 PM & $6: 21$ & 104 & $1: 07$ \\
\hline
\end{tabular}


The bus schedule showed variability across the two days. The first day began early, at 4:30 AM, completed 213 kilometers of travel, and finished the day at 4:13 PM. Across the nearly 12 hours of continuous service, the bus was idle for 3 hours and 39 minutes.

The second sample day comprised two periods of service. The first started at 5:10 AM, completed at 11:01 AM, and covered 105 kilometers. The bus was then out of service for 3 hours and 7 minutes at the Half Way Tree location. The second period started at 2:08 PM, finished at 8:30 PM, and covered 104 kilometers. The periods covered a combined 209 kilometers. The bus was idle for a little over an hour during each period of service.

If a charging station were available at the Rockfort depot, the hypothetical 259-kilometer BEB would be able to complete both days of service. The bus would need to charge overnight for the next day of service. The bus may benefit from a charging station at the Half Way Tree location if the bus regularly stops at that location for a long period. The bus had relatively few idle periods during the times of service, which would provide little opportunity to charge during service without schedule adjustment. 


\section{Estimated Battery Electric Bus Fuel Economy}

NREL investigated how BEB fuel economy might vary across the drive cycles analyzed using the Future Automotive Systems Technology Simulator (FASTSim) tool (Brooker et al. 2015). FASTSim accepts a drive cycle and estimates vehicle performance based on user inputs of a wide range of vehicle attributes and drivetrains. Concurrent to the development of this analysis, the NREL FASTSim team has been developing a BEB model in FASTSim based on a Proterra 12.1-meter BEB (Proterra 2019).

NREL has used this FASTSim BEB model to develop estimates of fuel economy for a hypothetical BEB operating on the JUTC drive cycles. The average fuel economies reported are designed to represent the periods of time the vehicle was in motion. Idle time is not incorporated into estimates. At this stage in the analysis, the estimates are not intended to predict final BEB performance. Rather the estimates are intended to show which drive cycles may result in better BEB performance and inform further analysis of possible JUTC bus electrification.

Figure 9 includes the resulting kilowatt-hour $(\mathrm{kWh})$ per kilometer estimates for each of the bus drive-cycles analyzed. As expected, there is variability within each geographic group across the individual drive cycles. The Portmore to Kingston and the Spanish Town to Kingston fuel economies show similar ranges across their drive cycles, and both overall cycles resulted in a $1.1-\mathrm{kWh} / \mathrm{km}$ estimate. The Spanish Town to Denbigh route resulted in an estimate of 0.9 $\mathrm{kWh} / \mathrm{km}$. The Stony Hill route provided the best estimate at $0.8 \mathrm{kWh} / \mathrm{km}$.

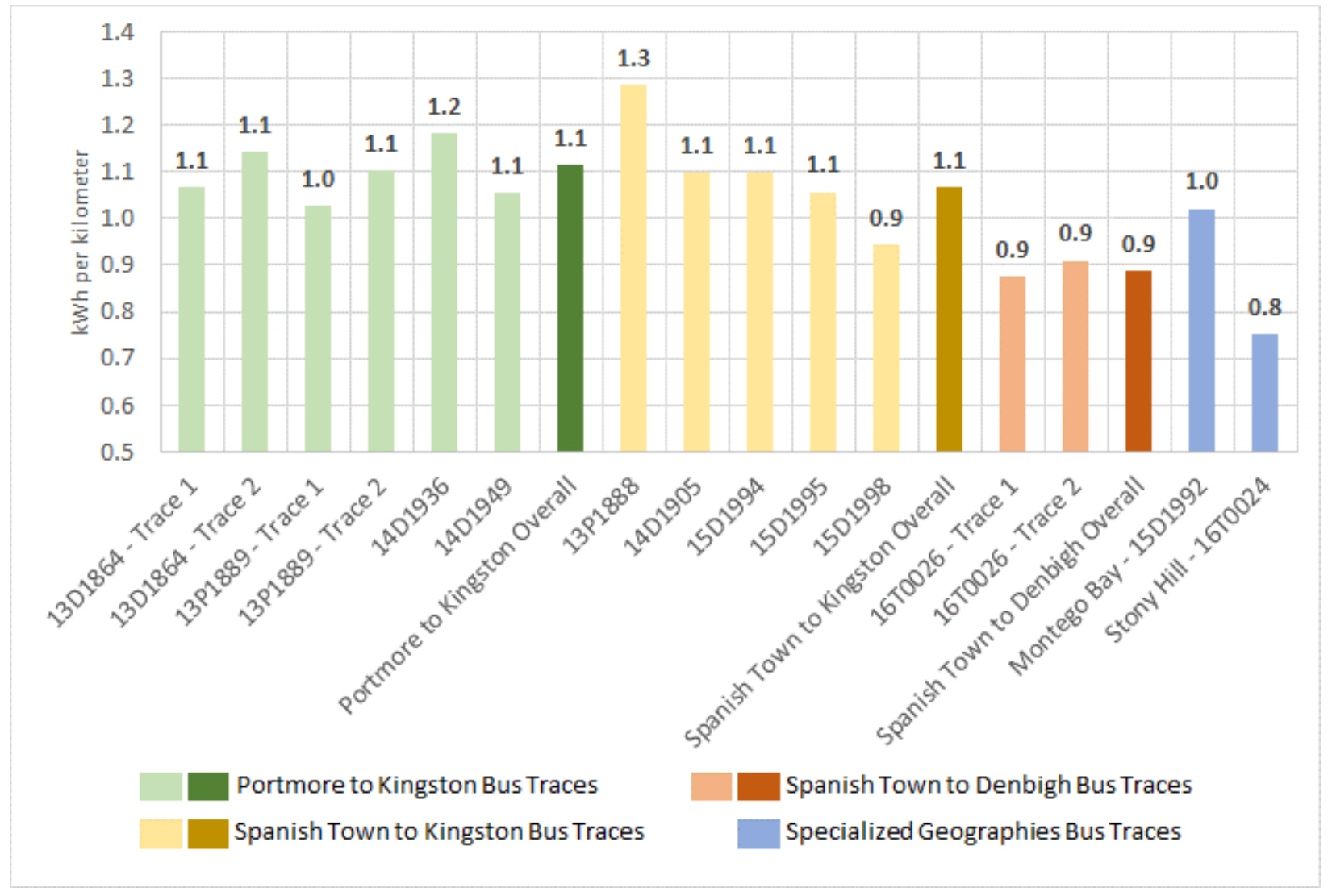

Figure 9. FASTSim BEB fuel economy estimates (kWh/km) 


\section{Discussion}

The NREL JUTC vehicle analysis provides an initial overview of the dynamics of the JUTC bus routes studied and highlights areas that may benefit from further investigation.

In general, the JUTC buses travel on average at a similar speed but stop more often than the 19 buses and 472 days of travel captured in the Fleet DNA database of mass transit buses. This would indicate that the JUTC buses are operating in a similar but somewhat more aggressive driving environment with more stop-and-start driving than the United States drive cycles captured in the Fleet DNA database. The kinetic intensities of some of the routes, especially the Stony Hill route, were elevated, which further highlights stop-and-start driving along these routes. Finally, the Stony Hill drive cycle resulted in the best BEB fuel economy estimate compared to the other routes.

The daily operations of the buses were sampled to determine the ability for hypothetical BEBs to charge overnight at their primary depot and cover the necessary distances of the current bus routes. Sample days in the Portmore to Kingston, Spanish Town to Kingston, and Stony Hill drive cycles showed it would be possible for a hypothetical BEB with a range of 259 kilometers to cover the necessary distance of the sample days. The Spanish Town to Denbigh route would require the hypothetical BEB to charge during the day to complete the distance. Any deployment of BEBs would require close management of how the BEBs were scheduled within a set of routes. As an example, the sample Portmore to Kingston routes showed the hypothetical BEB would not be able to cover the required distance of all the days studied. BEB use would need to be constrained to the routes within the range of the bus.

Beyond the operations of the buses discussed in this analysis, the JUTC will need to investigate charging infrastructure requirements and impacts. While specific charging infrastructure can vary depending on the specific buses implemented, working closely with the local utility should help the JUTC to appropriately site the required infrastructure and determine the compatibility of the charging load and the grid. Completing this analysis well in advance of any implementation efforts will allow the JUTC to minimize costs associated with installing charging equipment and charging buses.

This study has begun the process to determine the suitability of deploying BEBs in the JUTC system. Ultimately an onsite test of a BEB may be necessary to better understand performance in the local environment, but further model-based analysis could provide additional learnings such as the following:

- The JUTC bus route variability is not fully understood. The sample bus data logs often covered less than two full days of bus activity. To raise confidence in the assessments, data covering more days would be helpful.

- Modeled fuel economy estimates were based on an existing model of a 12.1-meter BEB. The FASTSim model could be updated to account for several factors including:

○ The technical specifications of a specific BEB under consideration.

- Elevation and grade changes for routes: The model used in this analysis assumed a flat route, but grade could significantly impact fuel economy. 
- Variable passenger counts and auxiliary loads: Variable passenger counts and auxiliary loads such as air conditioning use can impact BEB range and efficiency.

- Modeling a standard diesel bus's fuel economy on the JUTC drive cycles would allow for a comparison between the diesel fuel economy and the estimated BEB fuel economy. The BEB fuel economies presented in this analysis provide insight into where a BEB might be most efficient. Comparing these to estimated diesel fuel economies would highlight where the largest benefit for shifting to a BEB could be found. These results could inform a study of the total cost of ownership of the two technologies, including vehicle acquisition, fueling, maintenance, and infrastructure over the life of the vehicles. 


\section{Appendix A. Bus Route Traces}

\section{A.1 Portmore to Kingston}
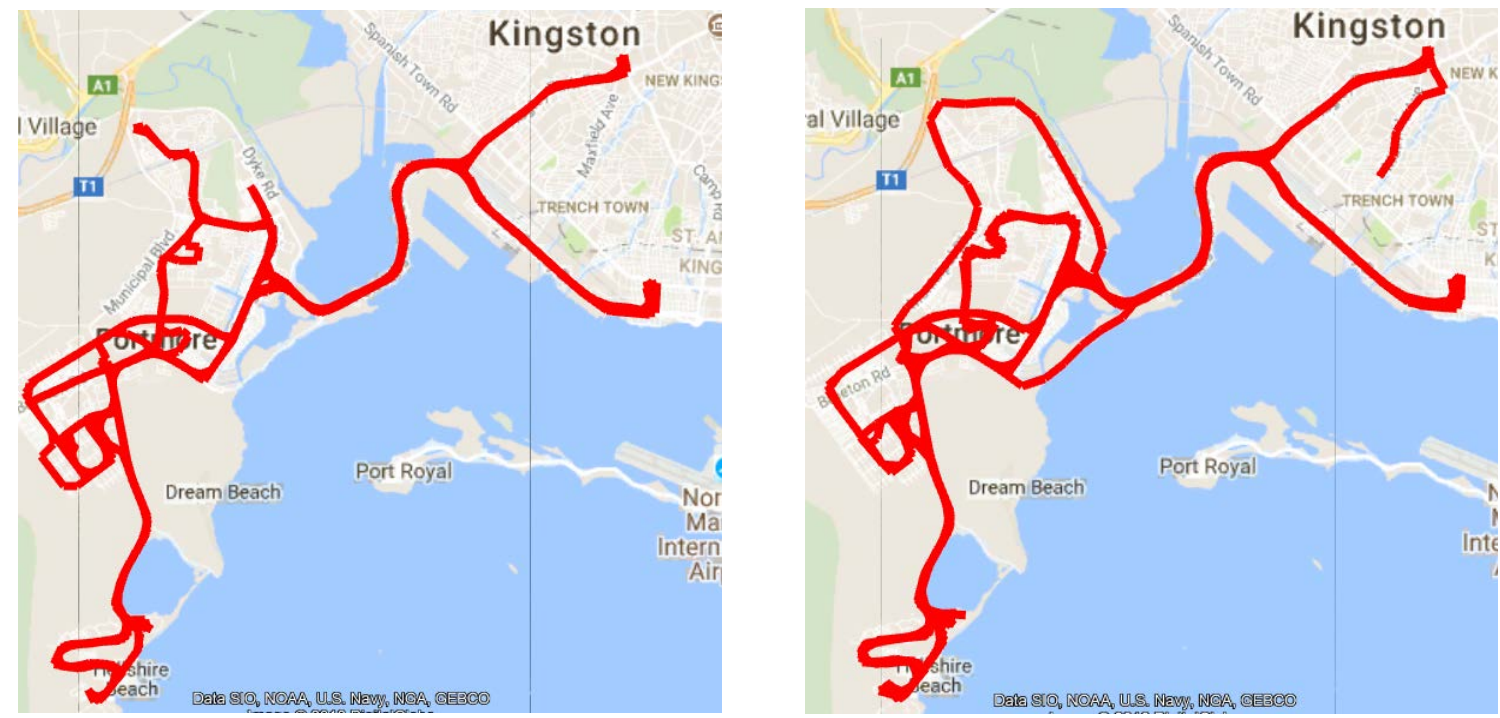

Figure A1.1. Bus 13D1864 Traces 1 and 2 (Google 2018)



Figure A1.2. Bus 13P1889 Traces 1 and 2 (identical) (Google 2018) 


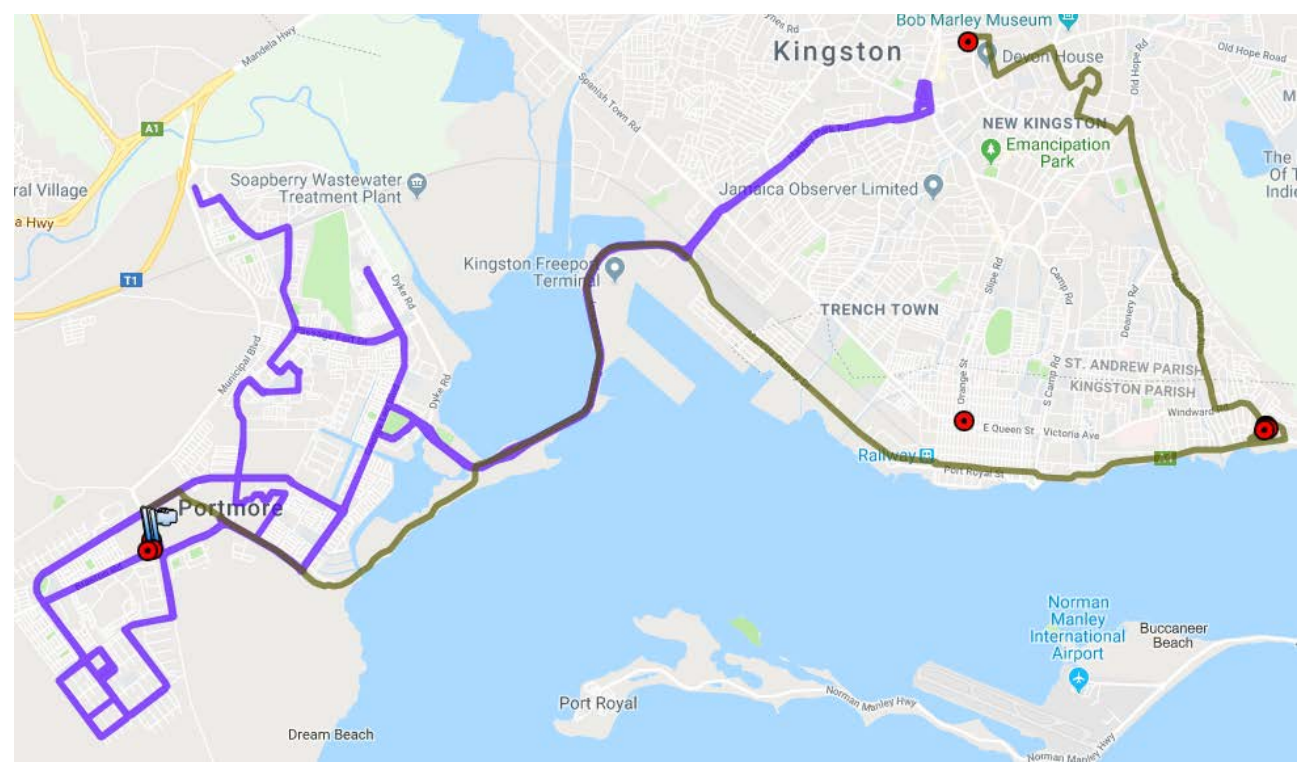

Figure A1.3. Bus 14D1936 Trace 1 (Google 2018)

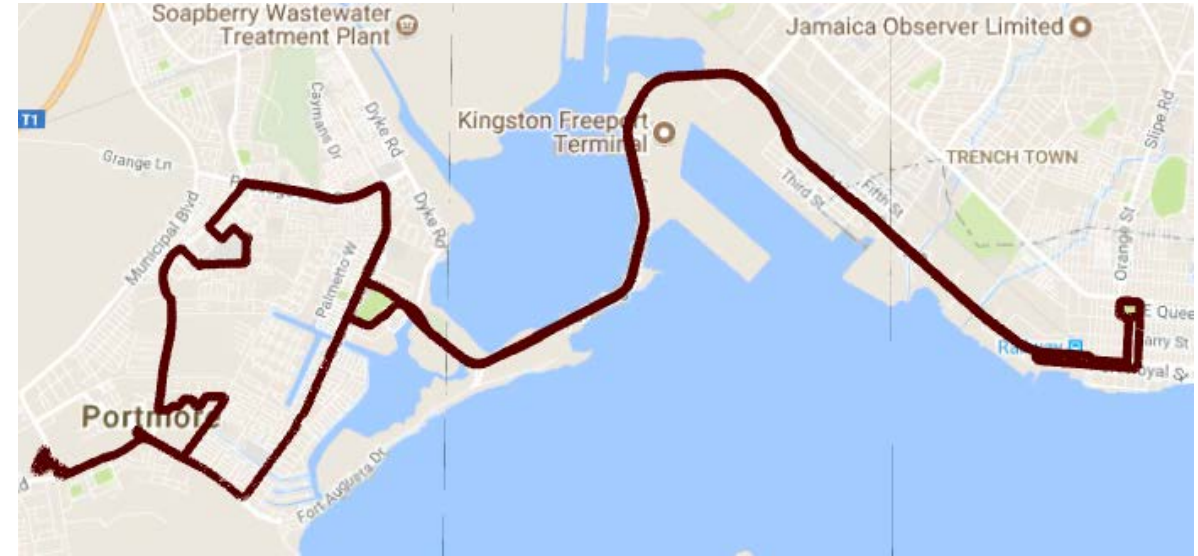

Figure A1.4. Bus 14D1949 Trace 1 (Google 2018) 


\section{A.2 Excluded Portmore to Kingston}



Figure A2.1. Bus 15D1988 Trace - Missing segments (Google 2018)



Figure A2.2. Bus 15D1991 Trace - 5-second data (Google 2018) 


\section{A.3 Spanish Town to Kingston}

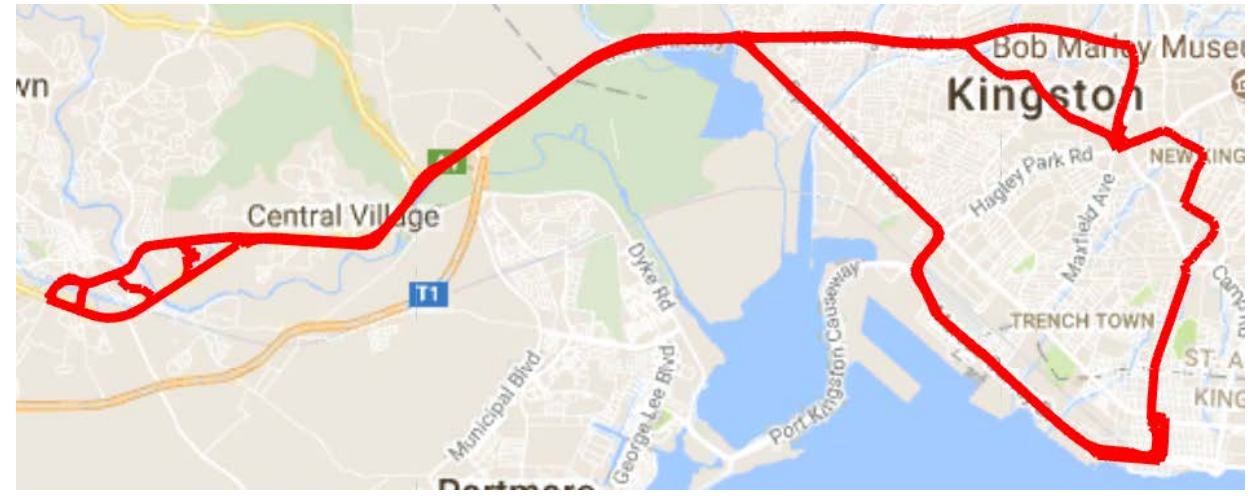

Figure A3.1. Bus 13P1888 Trace (Google 2018)

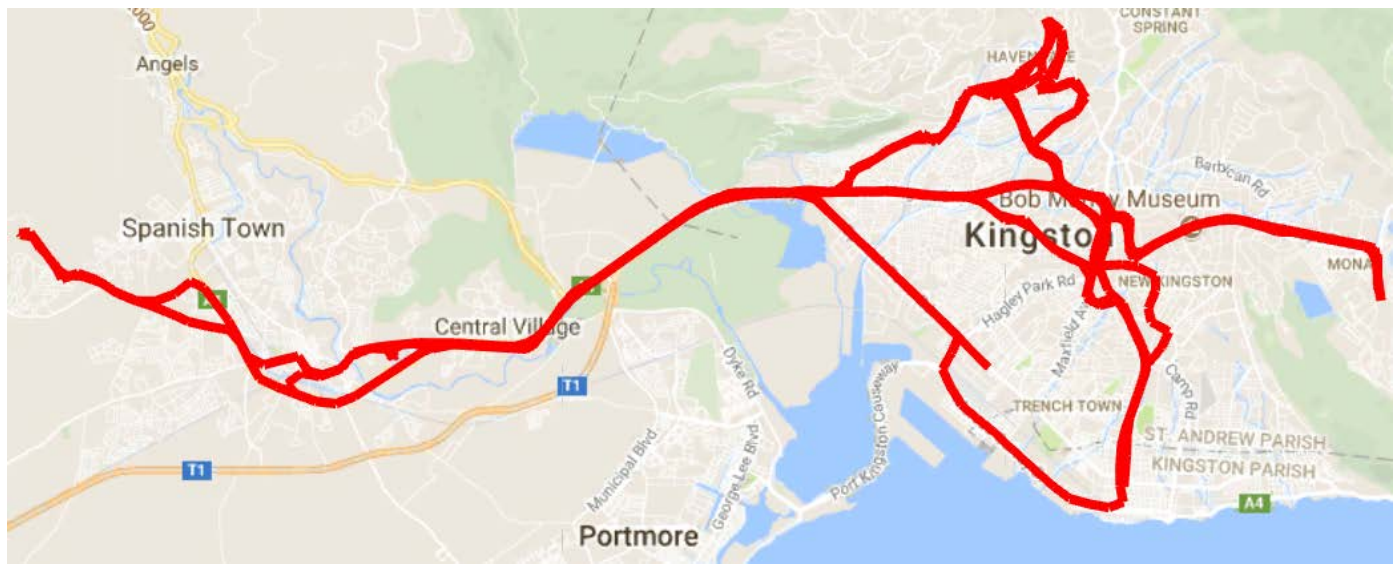

Figure A3.2. Bus 14D1905 Trace (Google 2018)

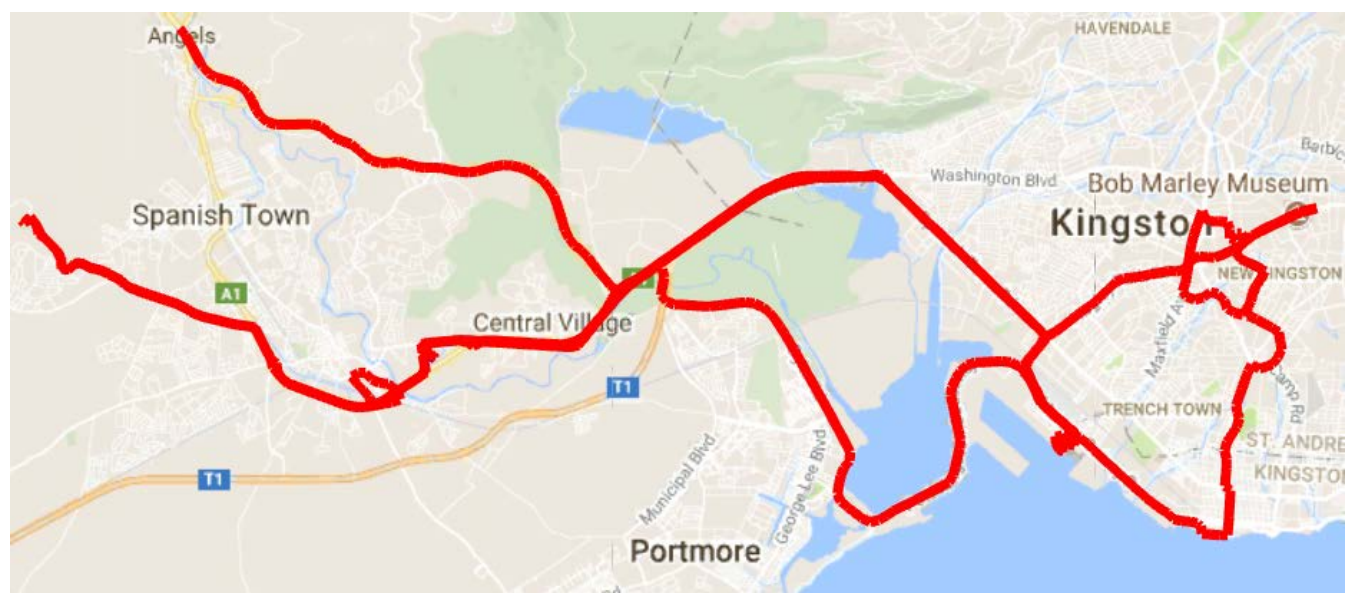

Figure A3.3. Bus 15D1994 Trace (Google 2018) 


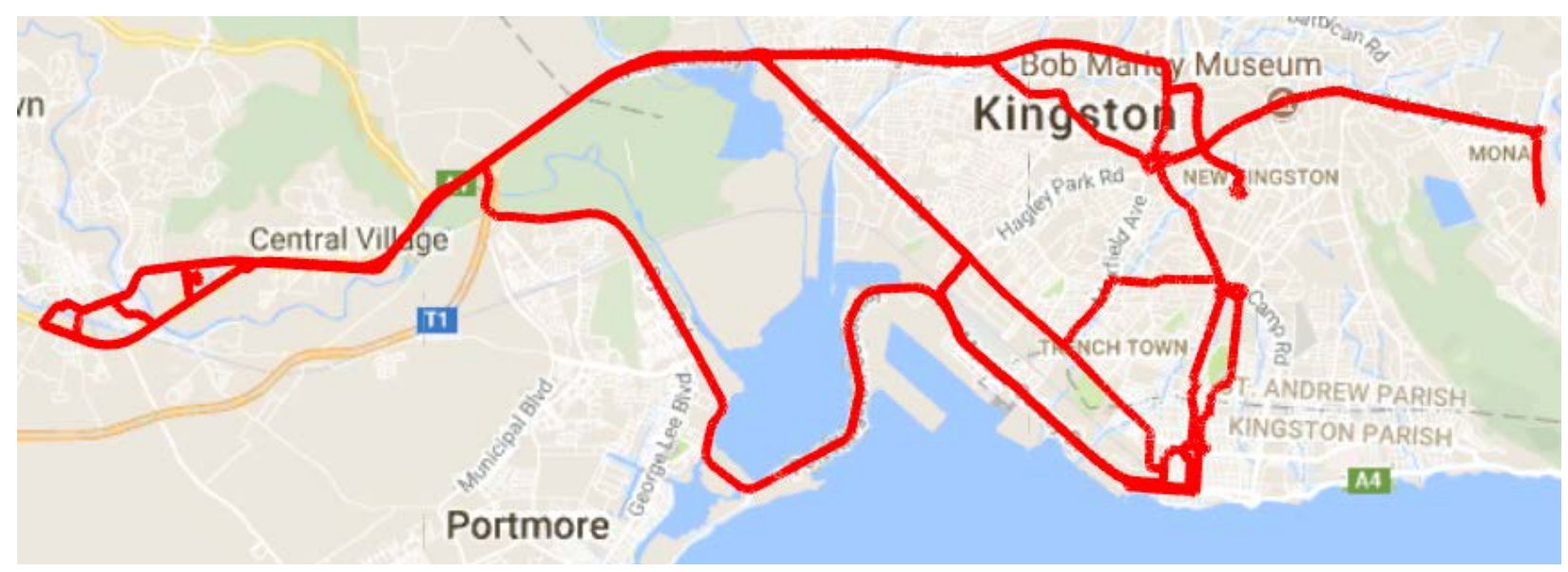

Figure A3.4. Bus 15D1995 Trace (Google 2018)

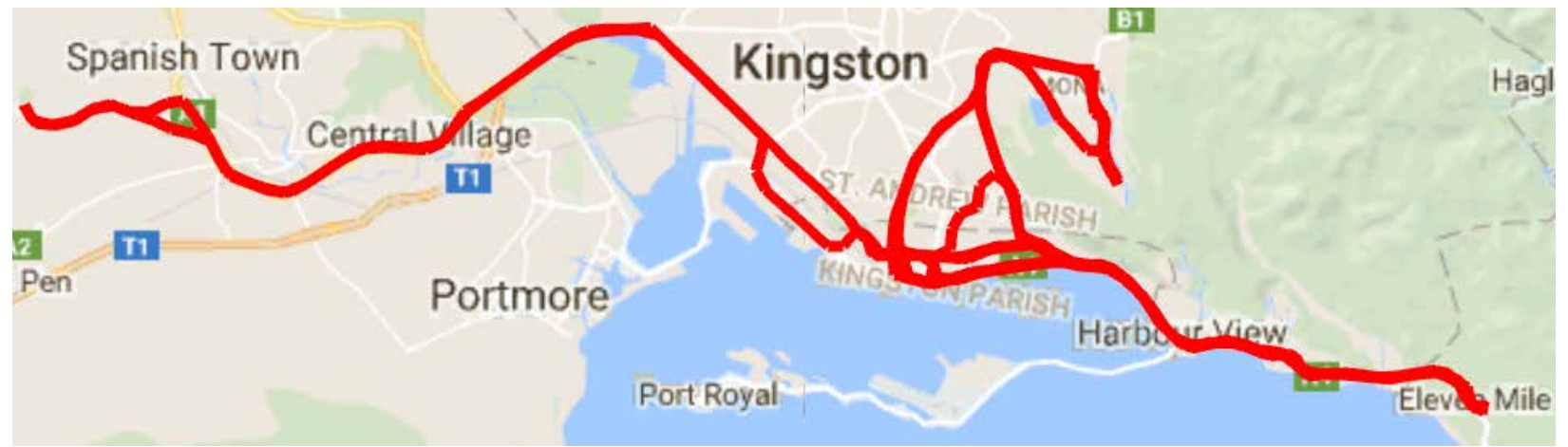

Figure A3.5. Bus 15D1998 Trace (Google 2018) 


\section{A.4 Spanish Town to Denbigh}



Figure A4.1. Bus 16T0026 Traces 1 and 2 (Google 2018)

\section{A.5 Beyond Kingston}

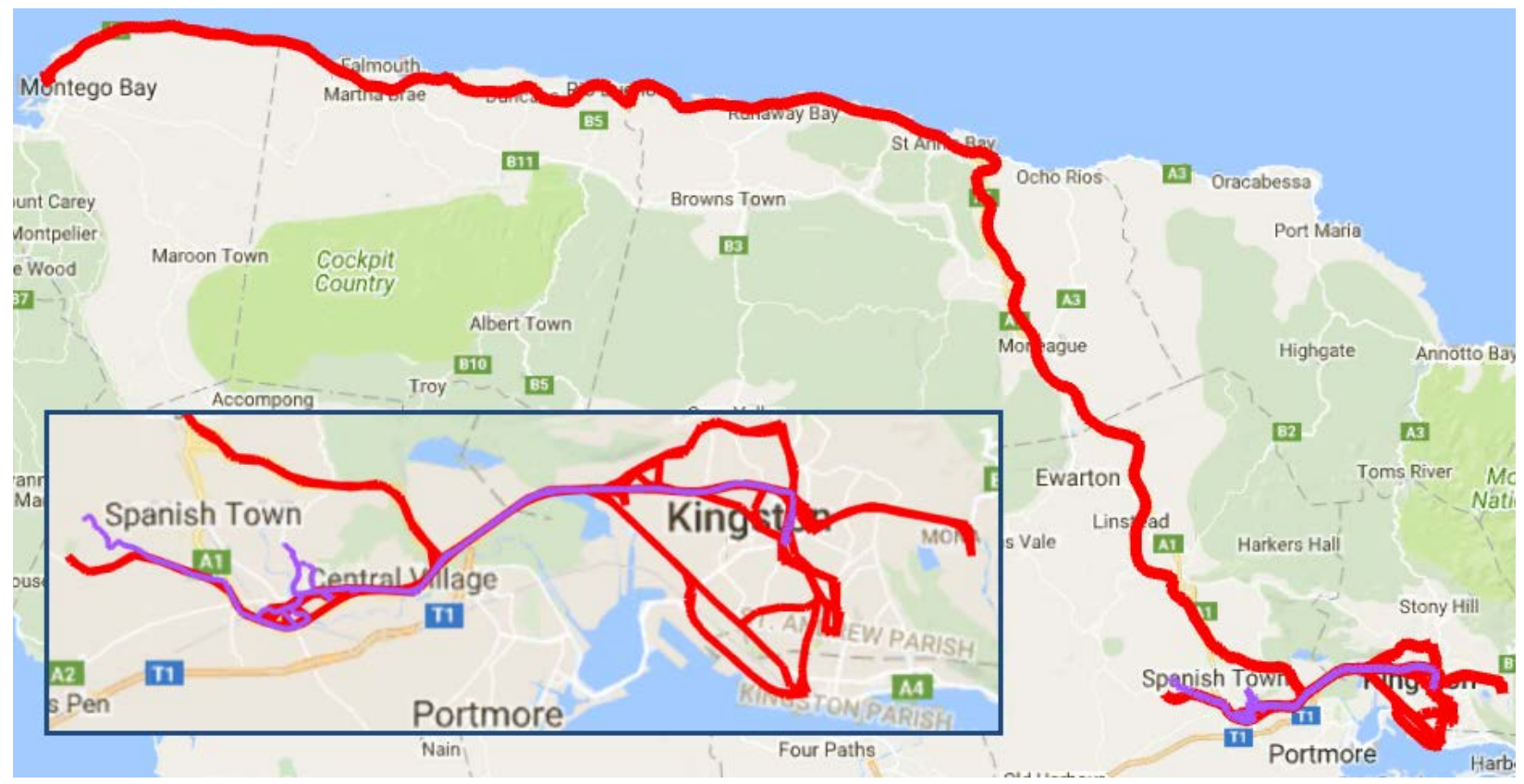

Figure A5.1. Bus 15D1992 Trace (Google 2018) 


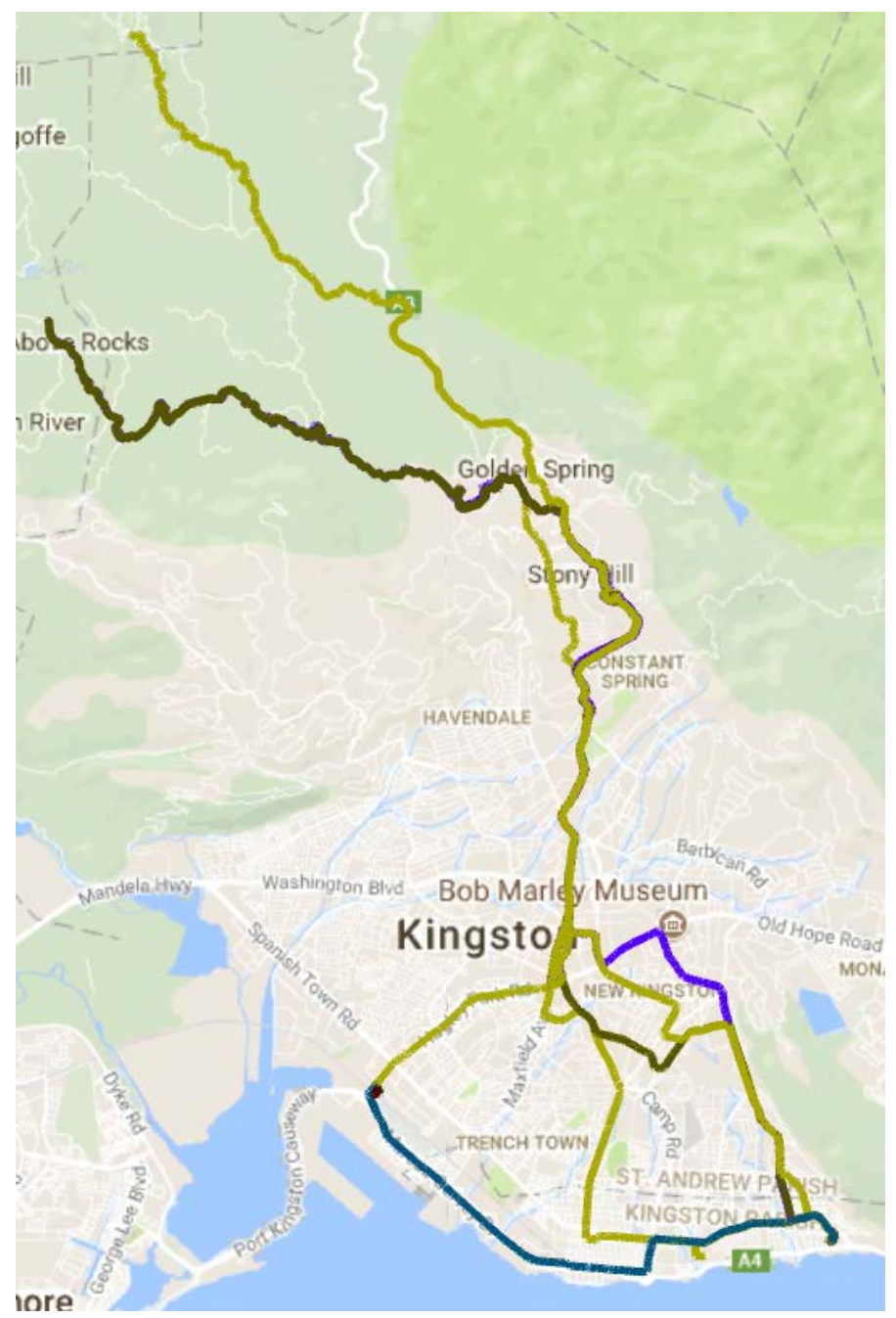

Figure A5.2. Bus 16T0024 Trace (Google 2018) 


\section{References}

Brooker, A., Gonder, J., Wang, L., Wood, E. et al. 2015. "FASTSim: A Model to Estimate Vehicle Efficiency, Cost, and Performance.” SAE Technical Paper 2015-01-0973, 2015, doi:10.4271/2015-01-0973. https://www.nrel.gov/transportation/fastsim.html

BYD Motors. 2018. Accessed July 13, 2018: www.byd.com/en/index.html.

National Renewable Energy Laboratory. 2013. "DRIVE Analysis Tool Generates Custom Vehicle Drive Cycles Based on Real-World Data.” NREL/FS-5400-54507.

National Renewable Energy Laboratory. 2018."Fleet DNA Project Data.” National Renewable Energy Laboratory. Accessed January 15, 2018: www.nrel.gov/fleetdna

O’Keefe, M., A. Simpson, and K. Kelly. 2007. "Duty Cycle Characterization and Evaluation Towards Heavy Hybrid Vehicle Applications." Golden, CO: National Renewable Energy Laboratory. NREL/CP-540-40929. Accessed July 24, 2018:

https://www.nrel.gov/docs/gen/fy07/40929.pdf

Proterra. 2019. "Proterra Catalyst Buses.” Accessed April 17, 2019: www.proterra.com/. 